\title{
Optimizing the Use of Musa spp. Waste in the Design of an Ethanol Production Plant
}

\author{
Ken Aldonza, Richard Blanchard*
}

School of Electronic, Electrical and Systems Engineering, Loughborough University, Loughborough, LE11 3TU, United Kingdom

\begin{abstract}
There is much in the scientific literature regarding the energy value of bioethanol, whether it is sustainable as a transition fuel and what impacts the production could have on food resource availability. This paper addresses these issues through the development of an energy self-sufficient ethanol plant. The plant utilizes waste Musa spp (banana) as the feed stock thereby making no additional demands food production. Solar energy and bioenergy provide thermal and electrical inputs to the process. The energy return on investment for this plant was calculated and a financial model drawn up to determine the economic feasibility of the plant. In one scenario, the operational cost of ethanol production is $£ 0.39 /$ litre with a profit before tax of $£ 44,000$ per year for a 460,000 litre facility. This scenario results in a maximum selling price for ethanol of $£ 0.45 /$ litre at an IRR of $11 \%$ for a 15 year operation which is comparable to current petrol prices. Furthermore, the process used is very simple and appropriate for s mall developing countries. The study focuses on the island of St. Lucia which is a banana producing state in the West Indies and concludes that establishment of an ethanol plant is possible with the right financial support with the benefit of reducing imports of petroleu m products, improving the balance of payments and creating employment.
\end{abstract}

\section{Keywo rds Ethanol, Process Model, Financial Model, Bioenergy, Anaerobic Digestion, Energy Ratio}

\section{Introduction}

St Lucia is an island in the Caribbean whose majority of transport and electrical energy requirements are met through imports of foreign petroleum products. Any ability to reduce this dependence will provide benefits of reduced foreign exchange expenditure, increased energy security and a strengthened economy.

There has been considerable interest in the potential for the use of ethanol as a biofuel, for example[1]. It is envisaged that St. Lucia's ethanol could be used in a $10 \%$ blend with petrol known as E10. Use of E10 petrol would require no modifications to existing vehicles[2], however, ethanol handling infrastructure will have to be installed at fuel depots to allow side stream blending[3]. Blending at the storage depots on the island is preferred as it would be cheaper and facilitate easier logistics.

St. Lucia has a long established banana industry which supplies the United Kingdom and neighbouring countries in the Caribbean. Exports vary depending on climatic conditions and since 2001 have ranged between 30,000 and 48,000 tonnes bringing an annual revenue of between XCD $\$ 41-58$ million[4]. However, the estimated reject rate

* Corresponding author:

r.e.blanchard@lboro.ac.uk (Richard Blanchard)

Published online at http $/ /$ journal.sapub.org/ep

Copyright (C) 2012 Scientific \& Academic Publishing. All Rights Reserved for St Lucia's bananas is $5 \%$ to $10 \%$ of production[5]. Approximately $7 \%$ of the rejected fruit has been sold into the domestic market according to the figures published in[5] with the remainder becoming waste. If this waste fruit can be procured and ripened, it can be fermented into ethanol.

When ripened green banana starch is converted to reducing sugars and sucrose, at $33.6 \%$ and $53.2 \%$ respectively[6]. Subsequently, if batch fermented, this has been shown to yield 0.07 litres of ethanol per $\mathrm{kg}$ of ripened banana feedstock without the use of hydrolyzing enzy mes [7]. This compares favourably with sugar cane ethanol which yields 0.0726 litres per $\mathrm{kg}$ of sugar cane[1]. Bananas take around 6 days [8] to ripen at average a mbient temperature of $28^{\circ} \mathrm{C}[9]$ in St. Lucia.

It has been reported in the literature that the ratio of energy, $R_{E}$, in a unit volume of ethanol to the non renewable energy used, to produce that volume of ethanol is between 1.29 and 1.65 for corn ethanol[10] and between 2[11] and 8.4[12] for sugar cane ethanol. This value is strongly dependent on the location of the ethanol facility, raw material and manufacturing process used[10] as well as consideration of embodied energy in fertilizer, fuel and capital equip ment. It is important that the $R_{E}$ in the process is $>1$ as this affects the financial systems and the broader view of the sustainability of ethanol production.

This work aims to use what is currently a waste agricultural product as a feedstock for producing ethanol using a plant designed to be self sufficient in energy. The 
proposed process model is designed to have no additional dependence on fossil fuel inputs and utilises a very productive continuous fermentation system.

A financial model of the process has been created to estimate its outputs and optimize economic performance. The economics of the process are examined through a determination of the internal rate of return (IRR) at a recommended premium sale price for the ethanol product. This retail price is determined primarily by benchmarking.

The impact of the entire process on use of non renewable energy inputs is then assessed through an estimation of energy return on investment $\left(\mathrm{R}_{\mathrm{E}}\right)$.

\section{Process Model}

Fig. 1 shows the design schematic of the proposed energy self-suffic ient ethanol plant. The following assumptions and limitations have been made for the model:

i. There are no customs duties on importation of capital equipment and operating materials. This is a condition of operation in a duty free zone on the is land.

ii. Banana production will be approximately of 42,500 tonnes per year for the following 15 years.

iii. There will be a single ethanol factory with a market guaranteed by government for the 15 years of operation.

iv. Financing will be obtained through government assistance at a discount rate of $11 \%$.

v. The process uptime is $93 \%$ of the year.

vi. The carbon dioxide generated during fermentation is not captured for sale and any ethanol vapour mixed in with it is not condensed. vii. The available feedstock is estimated at $7.5 \%$ of total banana production.

viii. Distillation removes $100 \%$ of the ethanol content of the beer.

ix. A $30 \%$ contingency allowance is applied to all capital costs. This is larger than usual to account for the extra risks of a new process.

$\mathrm{x}$. Ethanol sale price must be lower than petrol retail price.

All equipment except the stirred tank reactors, generator and solar panels will be located inside a naturally ventilated factory shell. The primary purpose of the buffer tanks is to supply an uninterrupted supply to the connected devices usually via pumps. Sampling valves are located between fermenters to allow monitoring of output conditions.

\subsection{Ethanol Production Process}

The process is designed to operate continuously at a nominal flow rate of $432 \mathrm{~kg} / \mathrm{h}$ of blended whole ripened banana mash diluted with $10 \%$ water and with an expected sugar concentration of $19.1 \% \mathrm{w} / \mathrm{v}$. The concentration of sugars in an undiluted mash is about $20 \% \mathrm{w} / \mathrm{w}[7]$.

Shell and tube heat exchangers are used to recycle heat among processes such that the process becomes thermally energy self sufficient when started. The water supply temperature is maintained at $79^{\circ} \mathrm{C}$ such that the distillation temperature[13] is automatically controlled since the distillation heat exchangers increase the preheated beer temperature to the water temperature. The $\varepsilon$-NTU method[14] was used to size all heat exchangers that operate in the counter flow mode. Heat exchangers are also used in the distillation and pasteurization processes with complete pasteurization occurring in the holding coil.

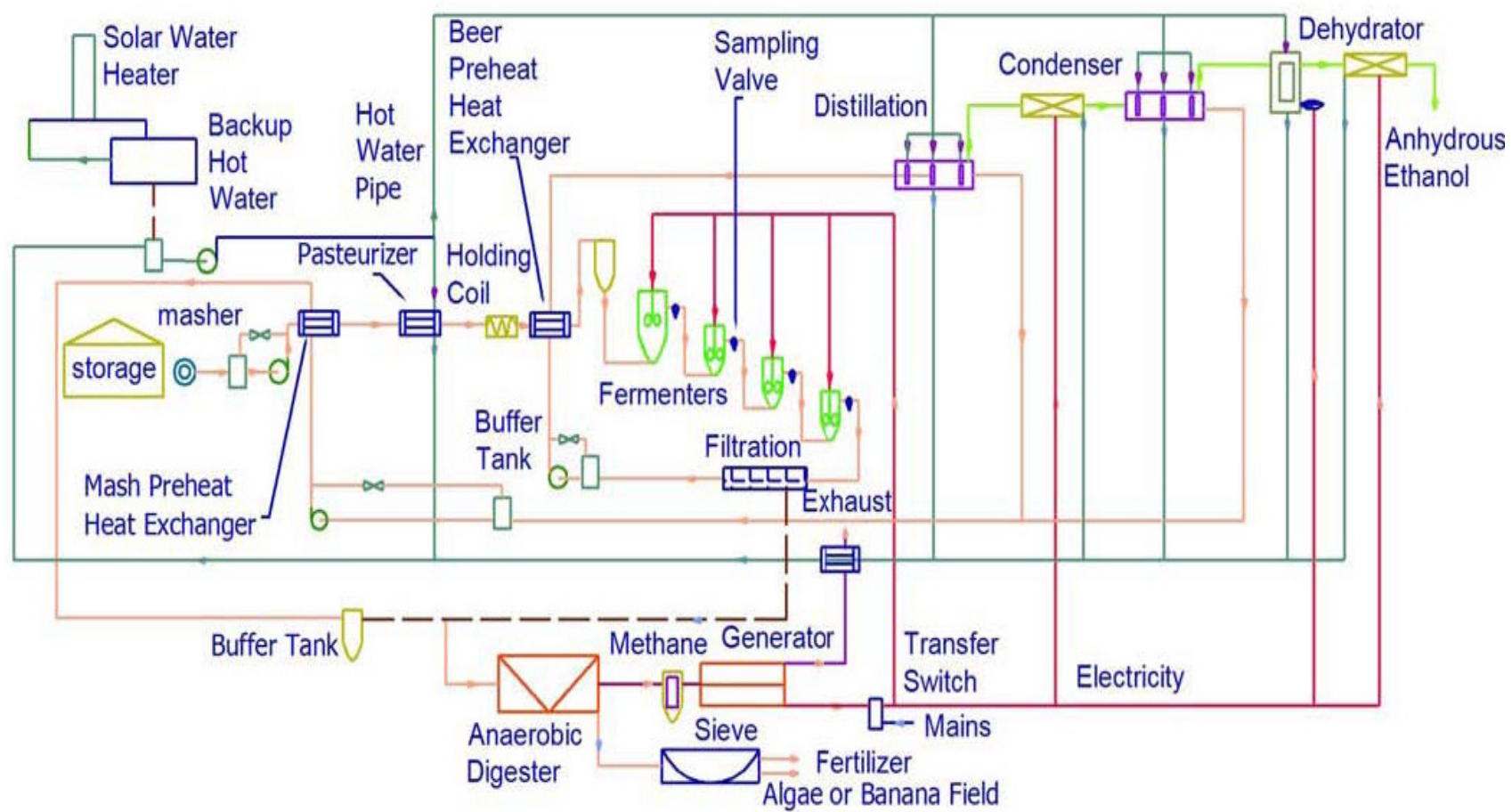

Figure 1. Schematic of banana ethanol process plant. The following colour coding is used: water system - blue; electrical syst em - magenta; banana puree - orange; ethanol vapour - green 
Four fermenters are used in series with the first being twice the size of the others at $3.5 \mathrm{~m}^{3}$ to maximise yeast growth. It has been shown that ethanol productivity is higher in the later fermenters and the expected ethanol concentration in the last fermenter is $10 \% \mathrm{v} / \mathrm{v}$ using an optimum dilution rate of $0.21 / \mathrm{h}$ with no yeast recycle or additions. Ethanol concentration would decrease in a fifth fermenter due to consumption by the yeast[15]. Continuous processing has been selected in preference to batch processing due to higher productivity, ease of automation and less demanding system preparation and labour. However, adequate operating conditions need to be implemented in order mitigate problems of contamination by organisms and equipment failure[16]. Strain degeneration can be handled through periodic reseeding of all the fermenters in the system. A thermotolerant flocculating variety of Saccharomyces cerevisiae has been sourced and will be used in the fermentation process without cell recycle. The strain will tolerate temperatures up to $37^{\circ} \mathrm{C}$ and ethanol concentrations up to $11 \%$. The $\mathrm{pH}$ of banana puree is around $4.8[17]$ so it is not anticipated that $\mathrm{pH}$ adjustments will be needed in the fermenters.

Distillation is a two stage process achieving $45 \% \mathrm{v} / \mathrm{v}$ in the first and $80 \% \mathrm{v} / \mathrm{v}$ ethanol concentration in the second stage[18]. Ethanol dehydration will be accomplished using banana starch adsorption, similar to the use of corn grits in corn ethanol plants. It has been suggested that the high amylopectin content in starch would result in better adsorption properties[19]. The starch composition of green banana pulp is similar to the endosperm of corn grain at $70-80 \%$ with the amylose content between only $16 \%$ and $40 \%$. The water retention capacity of banana starch ranges from $8.9 \mathrm{~g}$ of water per $100 \mathrm{~g}$ of starch at $50^{\circ} \mathrm{C}$ to $44.7 \mathrm{~g}$ of water per $100 \mathrm{~g}$ of starch at $90^{\circ} \mathrm{C}$. This starch is considered at least as functional as corn starch[6]. Corn grit starch has been shown to work with ethanol concentrations from $50 \%$ to $95 \%$ [20]. $99.5 \%$ pure starch will be prepared by blending in water[6] then it is dried by blowing heated air from a heat exchanger. The energy needed to regenerate the starch for recycling is taken as $530 \mathrm{~kJ} / \mathrm{kg}$ of anhydrous ethanol[21]. Condensation of ethanol vapours will be accomplished through the use of standard water chillers.

The increase in output due to enzyme use is modelled as an increase in initial sugar concentration of 1.1 to that of ripened bananas without enzymat ic hydrolysis [7].

Before recirculation, the entire water mass flow is reheated to operating temperature via an exhaust gas heat exchanger connected to the generator engine. The system heat losses have been estimated and are adequately replenished. A combination of metering pumps and return flow valves have been selected to control flow rates in the system. A single flat plate evacuated solar heater will be installed to maintain a backup water supply at operating temperature. This will be used for system start-up and to replace any lost water. The dehydrated ethanol is denatured with $2 \%$ petrol by volume and shipped to customers weekly using a fuel tanker and tractor cab.

\subsection{Electricity Production}

The expected vinasse flow rate is $378 \mathrm{~kg} / \mathrm{h}$ with a COD content of $53,700 \mathrm{mg} / 1$ with no sulphur content[7]. The vinasse will be anaerobically digested (AD)[22] in a stirred tank reactor (STR) with working volume of $192 \mathrm{~m}^{3}$ and the biogas produced will fuel a $16 \mathrm{~kW}$ generator. A day's biogas storage under pressure will be provided using pillow tanks. A second generator will be installed as a backup unit and to eliminate the need for excess gas flaring through the sale of excess power into the grid. Any poor quality biogas produced will be co-fired with propane. The equip ment was carefully selected to ensure that the system is electrically energy self sufficient. In the event of loss of both generators, a grid connection will provide power through a manual transfer switch.

The following assumptions were made for the reactor:

i. The organic loading rate for the reactor is $2 \mathrm{~kg} \mathrm{COD} / \mathrm{m}^{3}$ day.

ii. The COD removal efficiency is $70 \%$.

iii. The biogas yield is $0.33 \mathrm{~m}^{3} / \mathrm{kg}$ COD removed.

iv. The methane content of the biogas is $70 \%$.

$v$. The power generation efficiency is $30 \%$.

vi. The energy value of the biogas is $25 \mathrm{MJ} / \mathrm{m}^{3}$.

vii. The STR works at ambient temperature with no heating.

The biogas will be dried with moisture traps before compression and then storage. The generators will be supplied from the stored biogas. The waste water after AD will be fed into an algae pond[23] or used for irrigation if the factory is located near a banana farm. The solids will be sold to farmers as a soil conditioner for banana fields with the aim of recovering half of the feedstock cost. This is facilitated by the fact that effectively all the nutrients remain in the waste after $\mathrm{AD}[23,24]$.

\section{Financial Model}

The import costs of ethanol from the U.S. and Brazil, using a local freight forwarder, have been estimated in order to benchmark the selling price in St. Lucia. Apart from plant profitability, the selling price will also be affected by the petrol sale price in St. Lucia (table 5).

Four models were developed due to the high cost of construction and enzymes. Operating costs, taxes and legal fees for St. Lucia were estimated using a currently operating manufacturing facility as a benchmark as well as published data. The factory will be operated with 10 employees including technicians, material handlers, an administrator and an engineer. The maintenance cost is estimated as $6.8 \%$ of operating cost based on the corn wet milling process[1].

Reject bananas will be purchased from farmers at a cost of $£ 0.01$ (XCD\$ 0.05) per kilogram from two centralized trading locations.

A net present value (NPV) calculation was performed using an expected plant operating life of 15 years, the maximumperiod for a tax holiday in St. Lucia [25]. This was 
used to determine the IRR under different conditions e.g. discount rates. It is expected that financing for this plant when built will be $70 \%$ debt and $30 \%$ equity.

The following four scenarios were modelled:

i. Construction of a $650 \mathrm{~m}^{2}$ production facility at $£ 200 / \mathrm{m}^{2}$ and use of ripened bananas with no enzy matic hydrolysis.

ii. Leasing of a $650 \mathrm{~m}^{2}$ facility at $£ 2.04 / \mathrm{m}^{2}$ per month and use of ripened bananas with no enzymatic hydrolysis.

iii. Construction of a $650 \mathrm{~m}^{2}$ production facility at $£ 200 / \mathrm{m}^{2}$ and use of enzymatic hydrolysis of green bananas.

iv. Leasing of a $650 \mathrm{~m}^{2}$ facility at $£ 2.04 / \mathrm{m}^{2}$ per month and use of enzymatic hydrolysis of green bananas.

\section{Estimation of RE}

The method for a life cycle inventory analysis, as defined by ISO 14044 standard and set out in[26] was followed as closely as possible with a focus on energy flows. The functional unit used is 'Non-renewable energy input in MJ to produce fuel grade ethanol with higher heating value (HHV) of 23.6 MJ per litre. Energy inputs from the farming process including the embedded energy of the fertilizer, pesticides and in the diesel fuel used in shipping were accounted for. The energy used in the production of capital equip ment was not included in the study. Energy inputs into farming were investigated using the recommended banana farming methods[27]. The inputs to the processes shown in Fig. 2 were analysed. The analys is does not include the energy used in shipping of pesticides as data on the total quantity of pesticides used was not available.

Boxed
Fruit

\section{Results and Discussion}

\subsection{Process Outputs}

The process model yields 0.141 litres of ethanol per $\mathrm{kg}$ of fresh bananas with production of 1,328 litres per day from $9,428 \mathrm{~kg}$ of fresh bananas. The final ethanol concentration is assumed at $99 \%$. The expected ethanol yield per $\mathrm{kg}$ of ripened bananas is higher than reported for the batch process by about $72 \%$. Th is increase co mes as a consequence of the expected ethanol yield based on the starting sugar concentration used in the continuous four stage fermentation process at the optimum dilution rate.

Table 1 shows energy balances for the model co mpared to the results from equipment selection. The deficit is calculated as the difference between continuous consumption and generated. The difference between continuous and maximum electrical consumption is due to the intermittent operation of blending equipment. The results show that the system adequately supplies all the required thermal process energy. The process model predicts a return water temperature of $80.2^{\circ} \mathrm{C}$ out of the exhaust gas heat exchanger. Reduced hot water pipe insulation may be necessary to ensure that the water temperature falls to $79^{\circ} \mathrm{C}$ between the exhaust gas heat exchanger and the distillation tanks.

Table 1. Energy balances

\begin{tabular}{|c|c|c|}
\hline & Electricity/W & Heat/W \\
\hline Process model & & \\
\hline Continuous consumption & 3,870 & 18,404 \\
\hline Maximum consumption & 4,756 & 18,404 \\
\hline Generated & 13,985 & 32,632 \\
\hline Deficit & $-10,115$ & $-14,228$ \\
\hline Equipment selection & & \\
\hline Continuous consumption & 8,395 & 18,404 \\
\hline Maximum consumption & 16,595 & 18,404 \\
\hline Generated & 13,985 & 26,905 \\
\hline Deficit & $-5,590$ & $-8,501$ \\
\hline
\end{tabular}

The power available daily from biogas yields is about $14 \mathrm{~kW}$ of electricity and $33 \mathrm{~kW}$ of heat. Roughly $27 \mathrm{~kW}$ of heat power is captured by the exhaust gas heat exchanger. The maximum electrical power required just exceeds the generator rating. This is unlikely to have an adverse effect on system frequency as the intermittent blending processes are of very short duration and the two contributing processes need not occur simultaneously. The effect of the resulting voltage flicker on the system components would have to be investigated. The power needed for blending operations will be supplied from a daily quantity of $161 \mathrm{~m}^{3}$ compressed, stored biogas.

\subsection{Financial Scenarios}

Table 2. Currency conversion rates

\begin{tabular}{|c|c|}
\hline Currency & Equivalent to $£ 1$ \\
\hline East Caribbean Dollar (XCD) & 5.383 \\
\hline United States Dollar (USD) & 1.9965 \\
\hline
\end{tabular}

The applied currency conversion rates are given in table 2 . Table 3 shows financial results for use of enzymatic hydrolysis of green bananas. Scenarios iii and iv show unfavourable financial outcomes due to the higher effect of enzy me cost compared to increased revenue. These models will receive no further consideration as they predict operating at a loss.

Table 3. Financial results for scenarios iii and iv

\begin{tabular}{|c|c|}
\hline Constructed facility & $£$ \\
\hline Annual revenue & 212,591 \\
\hline Annual O\&M cost & 220,198 \\
\hline Operat ing profit & $-7,607$ \\
\hline Leased facility & $£$ \\
\hline Annual revenue & 212,591 \\
\hline Annual O\&M cost & 223,783 \\
\hline Operat ing profit & $-11,192$ \\
\hline
\end{tabular}

Fig. 3 shows a financial comparison between scenarios $i$ and ii. Of these two scenarios utilizing ripened bananas, leasing is found to be more viable than constructing a facility 
due to a higher IRR at each possible ethanol selling price. A ll further results will be with reference to scenario ii as any plant built should follow this model.

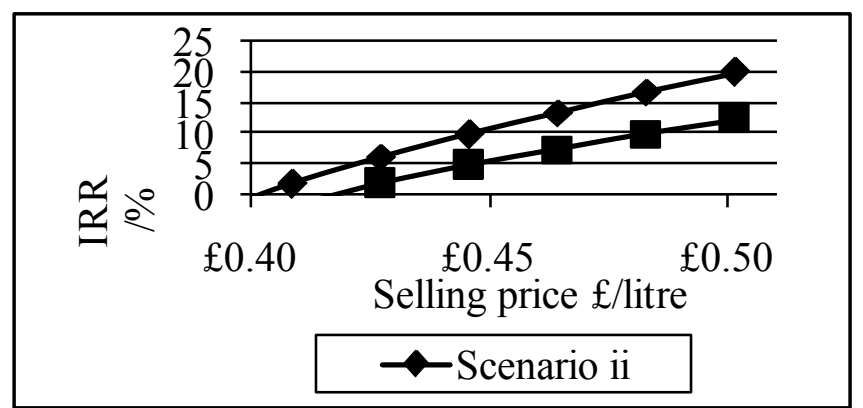

Figure 3. Internal rate of return versus ethanol selling price for scenarios $\mathrm{i}$ and ii

Table 4. Summary of costs and revenue

\begin{tabular}{|c|c|}
\hline Initial Costs & $£$ \\
\hline Installation & 13,004 \\
\hline Capital insurance and freight & 288,560 \\
\hline Legal fees & 7,729 \\
\hline Total & 309,293 \\
\hline O\&M Costs & $£$ \\
\hline Materials & 44,047 \\
\hline Administration and insurance & 65,072 \\
\hline Personnel & 55,731 \\
\hline Maintenance & 12,028 \\
\hline Total & 176,878 \\
\hline Revenues & $£$ \\
\hline Ethanol sales & 205,223 \\
\hline Fertilizer sales & 15,763 \\
\hline Total & 220,986 \\
\hline Gross operat ing profit & 44,108 \\
\hline Capital salvage at $10 \%$ depreciation & 46,970 \\
\hline
\end{tabular}

A summary of costs and revenues is given in table 4. All costs are for the assumed production levels and at the suggested ethanol retail price given in table 5 . The cost of feedstock is twice the fertilizer revenue. The operating and maintenance costs and revenues are annual values. The values represent an NPV of 0 for a 15 year operation. So me of the gross profits after taxes will be paid out as dividends and the remaining portion is expected to be reinvested in the plant.

Table 5. Est imated importation and retail costs of ethanol ${ }^{1}[28]^{2}[2]$

\begin{tabular}{|c|c|}
\hline & $£ /$ litre \\
\hline Cost of sugar cane ethanol production in Brazil $^{1}$ & 0.13 \\
\hline Impost cost from Brazil & 0.20 \\
\hline Cost of corn ethanol production in USA ${ }^{2}$ & 0.13 \\
\hline Import cost from USA & 0.20 \\
\hline Cost of banana ethanol production in St. Lucia & 0.39 \\
\hline Suggested retail price at 11\% IRR & 0.45 \\
\hline Retail price of petrol in St Lucia & 0.462 \\
\hline
\end{tabular}

Table 5 lists importation costs and suggested retail price for the ethanol. It assumes the same importation costs from the U.S.A. and from Brazil to St. Lucia. Estimates are based on production costs. If ethanol were purchased at the U.S retail price, it would cost about $£ 0.39$ per litre to be imported. This is equivalent to the production cost in St. Lucia. The estimates suggest that it would cost the same to import from the U.S. as from Brazil, but the actual cost depends heavily on shipping costs. Also, the mark-up for retail is not included in the estimates. It is possible to procure and retail ethanol below the premium suggested retail price, so government support will be needed to prevent this. It is also clear from these results that improving profitability should be focused more on borrowing money at a discount rate below $11 \%$ rather than on increasing ethanol selling price as there is only a small marg in between the recommended premium retail price and the price of petrol.

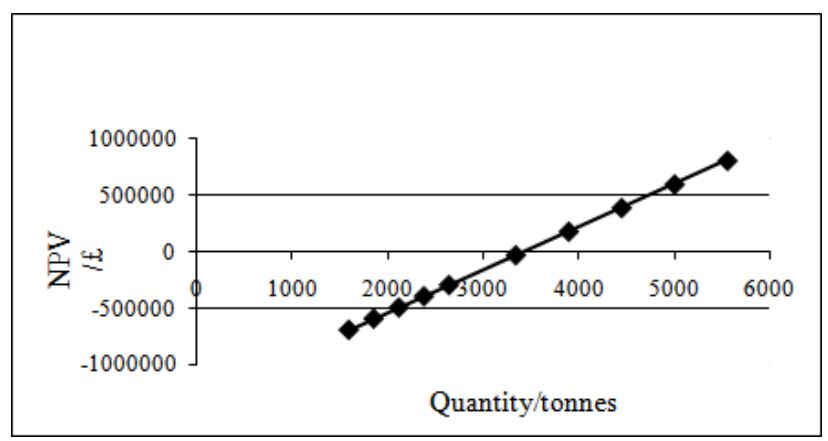

Figure 4. Net Present Value versus quantity of bananas processed into ethanol at $£ 0.45 / 1$ and discount rate of $11 \%$

Fig. 4 shows the effect of the quantity of bananas processed versus the NPV for the 15 year operation. It assumes the yield to be constant. From this, at least 3,500 tonnes of bananas would have to be processed yearly at a yield of $0.141 \mathrm{l} / \mathrm{kg}$ in order to be profitable. This is possible at a minimum production of 35,000 tonnes per year and reject rate of $10 \%$. If the reject rate is $5 \%$ then 70,000 tonnes minimum annual production will be required. This also represents the maximum production capacity of the designed facility due to limitations on equipment size. This design can therefore provide a maximum output of approximately 460,000 litres per year. Increasing output is also limited by the is land's banana production volume.

The empirical relationship, $\left(\cos t_{1} / \cos t_{2}\right)=\left(\operatorname{size}_{1} / \operatorname{size}_{2}\right) n$ ( $n=0.75$ for fermentation processes), may be used for costing a suitably sized pilot plant to $\pm 15 \%[16]$. Using this relation to scale up the banana ethanol plant to 75.7 million litres per year, a typical corn ethanol plant size, and applying the total operating and maintenance cost from table 4 , the expected production cost becomes $£ 0.11$ per litre. This is within $15 \%$ of the sugar cane and corn ethanol production costs in table 5. The higher banana ethanol production cost is due to the small scale of this plant which is only a fraction of the size of corn ethanol plants in the U.S. or sugar cane ethanol plants in Brazil.

There are many factors that can affect the output and profitability of the ethanol plant thus making a quantification of the error in calculations difficult. The most influential factor is considered to be the ethanol yield. Fig. 5 is a plot of IRR against ethanol yield which illustrates the sensitivity of the economics of the plant to ethanol yield. In this case, if the process yield goes below $10 \%$, it is necessary to make improvements to increase it. The minimum acceptable 
operating yield will be dictated by the applied discount factor.

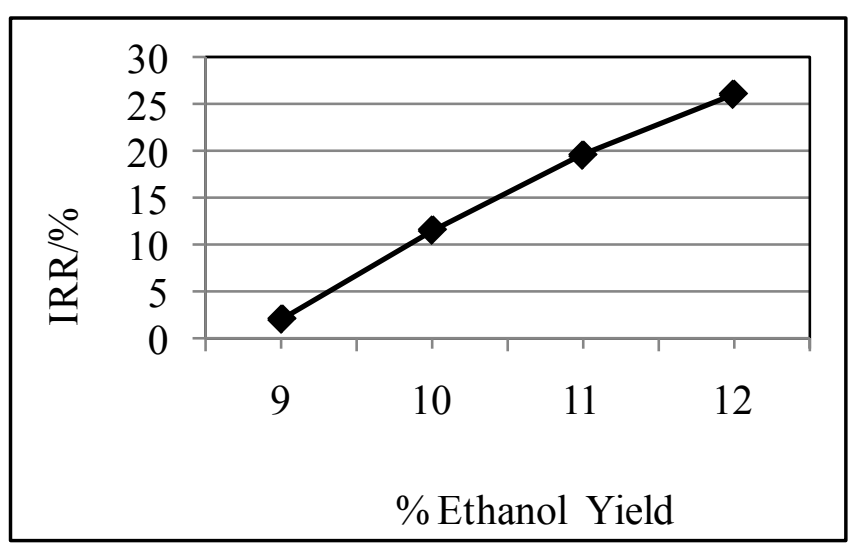

Figure 5. Ethanol yield versus internal rate of return

\subsection{Life Cycle Inventory Analysis}

The main results are shown in table 6. The embodied energy data used for fertilizer were obtained from[29] and for pesticides were obtained from[30]. All shipping and transportation assume use of diesel fuel.

Table 6. Fossil fuel energy inputs in banana ethanol production

\begin{tabular}{|c|c|c|}
\hline Item & Fossil Energy MJ/1 EtOH & Contribution \\
\hline Fertilizer & 5.5 & $39 \%$ \\
\hline Pesticides & 6.3 & $45 \%$ \\
\hline Ocean shipping & 2.1 & $15 \%$ \\
\hline Land transport & 0.27 & $2 \%$ \\
\hline Total & 14.2 & \\
\hline $\mathrm{R}_{\mathrm{E}}$ & 1.66 & \\
\hline
\end{tabular}

The farming process relies heavily on the use of fungicides and herbicides with the result that the highest source of fossil fuel use comes from these sources. Fertilizer is the next biggest contributor. The obtained estimate for $R_{E}$ is marg inally higher than for corn ethanol, possibly due to the fact that farming is very labour intensive in St. Lucia but is similar to values for banana fruit shown by[31]. The value is within the range for corn ethanol[1,10] but would vary depending on actual farming practices used. The results were derived from recommended practices published by the local Ministry of Agriculture.

The contribution from pesticide shipping is expected to be similar to that from fertilizer shipping depending on the quantity of pesticides. This would suggest a lower value of $\mathrm{R}_{\mathrm{E}}$ than calculated. The value of $\mathrm{R}_{\mathrm{E}}$ may be improved through shipping of pesticides together with fertilizers in order to reduce the total number of shipments and through reduced dependence on pesticides and fertilizers. This could be facilitated by use of the digestate fertilizer generated by the $\mathrm{AD}$ process.

\section{Quality Control}

Equipment has been selected to monitor and facilitate adjustment of the following parameters in order to ensure smooth system operation: i. The ratio of acidity to alkalinity in the bio reactors.

ii. The temperature in the bioreactors and of the hot water supply.

iii. Ethanol concentrations in liquids.

iv. Biogas composition.

$\mathrm{v}$. $\mathrm{pH}$ inside of bioreactors.

In addition, a supply of lime has been included in the operating costs for the purpose of increasing digester working $\mathrm{pH}$.

The ethanol is denaturized with $2 \%$ petrol[32] before shipping. This process will result in an increase in operating costs each time the price of petrol, which is currently subsidized, is increased.

\section{Conclusions and Recommendations}

The process model developed in this research has predicted a fermentation system with a higher output than a batch process from an energy self-sufficient ethanol plant.

The cost of producing the banana ethanol has also been estimated through the financial model analysis and though it is high due to a lack of economies of scale, the premium estimated selling price of the ethanol is still competitive with the price of petrol. The gross annual operating profit for the plant under the given assumptions is $£ 44,108$. It is expected that most of this will be paid off as dividends after deduction of income tax of $33.3 \%$.

The energy balances also indicate the process can produce all of the energy that the facility needs once it is started. The $\mathrm{R}_{\mathrm{E}}$ is predicted to be within the same range as for corn ethanol in addition to having the benefit of generating revenue from a waste agricultural produce.

The main drawback following from the results of this study is that any banana ethanol plant will need government support, whether through tax exemptions, subsidizing or reduced subsidies on petrol, in order to provide a substantial financial return on investment. Support will also be needed to procure funding such that the applied discount rate is lower than the maximu m of $11 \%$. Business loan bank interest rates in St. Lucia currently exceed $12 \%$. Sufficient support may also allow a higher price to be paid to farmers for the banana feedstock.

Further experimental work will be needed to determine optimum operating parameters for banana starch use as a desiccant. This may not affect start-up costs as corn grits can be used as a model. A lternatively membrane filters could be used, but this would require remodelling the system's energy requirements.

Profitability can be improved by reducing feedstock cost. However, if the price is too low, farmers may not have enough incentive for selling the rejected product. There is no cost to dispose of waste in St. Lucia. An incentive for the purchase of AD fertilizer is obtained from a higher sale price for organically grown bananas.

The anaerobic digestion process will need experimental investigation to determine whether sufficient nutrients are 
always available to sustain the digestion process. Digester layout and optimum organic loading rates may also require further experimental investigation to determine optimum operating parameters. The fertilizer value and optimum application rates of the waste, both solids and liquids, from AD will have to be determined through experimental investigation. When this is done, pricing can be reviewed to reflect its value as a soil conditioner. It is recommended that this plant be built near a large banana farm to ensure maximum use of both liquid, for irrigation, and solid, as a soil conditioner, $\mathrm{AD}$ digester waste and to minimise transportation costs.

Biogas production quantity and volumes will need to be monitored in order to ensure the min imu m calcu lated a mount and sufficient quality for use in a biogas generator. A power purchase contract will have to be established with the local power company to allow export of excess electricity into the power grid instead of flaring off excess biogas.

\section{ACKNOWLEDGEMENTS}

The authors acknowledge the support of IDEAS Scheme for the financial prize awarded to this project.

\section{REFERENCES}

[1] H. Shapouri, M. Saassi and N. Fairbanks. 2006. The economic feasibility of ethanol production from sugar in the United States. USDA, United States. Available: http://www. usda.gov/oce/EthanolSugarFeasibility Report3.pdf

[2] Department of Energy, U.S. 2012. Alternative \& Advanced Fuels.Available:http://www.afdc.energy.gov/afdc/fuels/ethan ol_blends.html

[3] Daniel Measurement and Control Inc. 2006. An introduction to ethanol blending - application guide. Emerson Process Management, Available:http://www.emersonprocess.com/da niel/Library/Liquid/AppNotes/General/IEB_Customer.pdf

[4] O. Joseph. 2009. Banana production, exports and revenue. Available: http://www.stats.gov.lc/A gri2.htm

[5] Ministry of Agriculture Forestry and Fisheries, St.Lucia. (2009), Annual A gricultural Review 2009. Government of St.Lucia, St.Lucia. Available: http://malff.com/images/storie s/agridigest/Annual\%20A gri\%20Review\%202009.pdf

[6] P. Zhang, R. L. Whistler, J. N. BeMiller and B. R. Hamaker, 2005. "Banana starch: production, physicochemical properties, and digestibility-a review," Carbohydrate Polymers, vol. 59, pp. 443-458.

[7] J. B. Hammond, R. Egg, D. Diggins and C. G. Coble 1996, "Alcohol from ban anas," Bioresource Technology, vol. 56, pp. 125-130.

[8] C. R. Chen and H. S. Ramaswamy, 2002. "Color and Texture Change Kinetics in Ripening Bananas," LebensmittelWissenschaft Und-Technologie, vol. 35, pp. 415-419.

[9] U.S National Weather Service. 2011. Current weather conditions, Hewanorra International Airport, St. Lucia. Available: http://weather.noaa.gov/weather/current/TLPL.ht $\mathrm{ml}$

[10] R. Hammerschlag, 2006. "Ethanol's Energy Return on Investment: A Survey of the Literature 1990 - Present," Environmental Science Technology, vol. 40, pp. 1744--1750.

[11] A. E. Wheals, L. C. Basso, D. M. G. Alves and H. V. Amorim, 1999. "Fuel ethanol after 25 years," Trends in Biotechnology, vol. 17, pp. 482-487.

[12] C. A. Garcia, A. Fuentes, A. Hennecke, E. Reigelhaupt, F. Manzinin, O. Masera, 2011. "Life-cycle greenhouse gas emissions and energy balances of sugarcane ethanol production in Mexico," Applied Energy, vol. 88, pp. 2088-2097.

[13] Commercial Alcohols Inc. 2011. Ethyl alcohol (anhydrous) material safety datasheet. Available: http://www.comalc.com/msds/pdf3/MSDS_English_Ethyl_ Alcohol_(Anhydrous)_Feb_2011.pdf

[14] K. S. N. Raju, 2011. Fluid Mechanics, Heat Transfer and Mass Transfer. USA: John Wiley and Sons, pp. 322-324.

[15] D. P. Bayrock and W. M. Ingledew, 2001. "Application of multistage continuous fermentation for production of fuel alcohol by very-high-gravity fermentation technology," Journal of Industrial Microbiology and Biotechnology, vol. 27, pp. 87-93.

[16] P. F. Stanbury, A. Whitaker and S. J. Hall.1998. Principles of Fermentation Technology. Second Edition. Great Britain: Butterworth Heinemann, pp. 357.

[17] P. Aegerter and C. Dunlap, 1980. "Culture of Five Commonly Used Acid-Producing Bacteria on Banana Pulp," Applied and Environmental Microbiology, vol. 39, pp. 937-942.

[18] N. Vorayos, T. Kiatsiriroat and N. Vorayos, 2006. "Performance analysis of solar ethanol distillation," Renewable Energy, vol. 31, pp. 2543-2554.

[19] K. E. Beery and M. R. Ladisch, 2001. "Chemistry and properties of starch based desiccants," Enzyme and Microbial Technology, vol. 28, pp. 573-581.

[20] B. Tanaka and L. Otten, 1987. "Dehydration of aqueous ethanol," Energy in Agriculture, vol. 6, pp. 63-76.

[21] M. R. Ladisch, M. Voloch, G. T. Tsao, P. Bienkowski and J. Hong, 1984. "Cornmeal adsorber for dehydrating ethanol vapors," Industrial \& Engin eering Chemistry, Process Design and Development, vol. 23, pp. 437-443.

[22] C. Eskicioglu, K. J. Kennedy, J. Marin, B. Strehler. 2011. "Anaerobic digestion of whole stillage from dry-grind corn ethanol plant under mesophilic and thermophilic conditions." Bioresource Technology, vol. 102, pp. 1079-1086.

[23] A. C. Wilkie, K. J. Riedesel and J. M. Owens, 2000. "Stillage characterization and anaerobic treatment of ethanol stillage from conventional and cellulosic feedstocks," Biomass and Bioenergy, vol. 19, pp. 63-102.

[24] F. M. Hons, J. T. Cothren, J. C. Vincent and N. L. Erickson, 1993."Land application of sludge generated by the anaerobic fermentation of biomass to methane," Biomass and Bioenergy, vol. 5, pp. 289-300.

[25] Tropical Web Shop. 2011. Doing Business (St.Lucia). Available: 
http://www.visitslu.com/doing_business/biz_environ/taxatio n.html

[26] ISO. 2006. "Environmental management - Life cycle assessment - Requirements and guidelines ISO 14044." Geneva, Switzerland: International Standardization Organization.

[27] Banana Emergency Recovery Unit Technology Package Producing Bananas with Tissue Culture Planting Material, 1st ed. St. Lucia: St. Lucia Ministry of Agriculture, Forestry and Fisheries, 2007, pp. 12.

[28] D. Luhnow and G. Samor. 2006. As Brazil fills up on ethanol, it weans off energy imports. The Wall Street Journal Available: http://yaleglobal.yale.edu/display.article?id=6817

[29] C. A. Ramírez and E. Worrell, 2006. "Feeding fossil fuels to the soil: An analysis of energy embedded and technological learning in the fertilizer industry," Resources, Conservation and Recycling, vol. 46, pp. 75-93.

[30] Z. R. Helsel. 1993, Energy and alternatives for fertilizer and pesticide use. Available: http://www.sarep.ucdavis.edu/newsl etters/archive/v5n5.pdf/view

[31] H. J. Velasquez-Arredondo, A. A. Ruiz-Colorado and S. De Oliveira Junior. 2010. "Ethanol production process for banana fruit and its lignocellulosic residues: energy analysis." Energy, vol. 25, pp 3081-3087.

[32] International Fuel Quality Center. 2004, Setting a quality standard for fuel ethanol. Available: http://www.environmen t.gov.au/atmosphere/fuelquality/publications/pubs/ifqc-repor t.pdf 